\title{
THE COURT AFFIRMS THE SOCIAL CONTRACT
}

\author{
Jack M. Balkin
}

In civics class we learn that federal courts decide whether laws passed by Congress and the state legislatures are constitutional. Therefore the federal courts are the guardians of our Constitution. That is certainly true, but it is not the whole story. In fact, the most important function of the federal courts is to legitimate state building by the political branches. That is the best way to understand what happened in the Health Care Case. ${ }^{1}$ It also helps explain why Chief Justice John Roberts's opinion is written the way it is.

What is "state building?" Throughout our country's history, government has taken on many new functions. The early nineteenthcentury American state actually didn't do very much more than national defense and customs collection. The executive branch was tiny. Over the years, the federal government took on more and more obligations, offering new protections and new services for its citizens. After the Civil War, Congress passed a series of civil rights laws, it created the Interstate Commerce Commission to regulate railroads, it passed an income tax, and early in the twentieth century it created a central bank. State building really took off after the New Deal, which established the modern administrative and regulatory state and added a host of labor and consumer protection regulations, investments in infrastructure, and Social Security. The national security state was born after World War II, and the 1960s brought new civil rights laws and new social welfare programs through the Great Society. At the turn of the twenty-first century, the federal government expanded its national security infrastructure even

${ }^{1}$ NFIB v. Sebelius, 132 S. Ct. 2566 (2012). 


\section{THE COURT AFFIRMS THE SOCIAL CONTRACT}

further, implementing vast new surveillance programs and strategies for dealing with terrorism-including detention of "enemy combatants" that I collectively call the National Surveillance State.

Whenever the federal government expands its capabilities, it changes the nature of the social compact. Sometimes the changes are small, but sometimes, as in the New Deal or the civil rights era, the changes are big. And when the changes are big, courts are called on to legitimate the changes and ensure that they are consistent with our ancient Constitution. In this way, courts ratify significant revisions to the American social contract.

The words "legitimate" and "ratify," however, are ambiguous terms. Courts do not simply rubber-stamp what the political branches do. Rather, they set new ground rules. The government may do this as long as it doesn't do that. Legitimation is Janus-faced: it establishes what government can do by establishing what the government cannot do.

When the judiciary is staffed by people more or less allied with changes in governance, courts legitimate them fairly easily. But when the federal judiciary is staffed by people hostile to a new president's program, it often casts a skeptical eye on the innovations. Then there can be a protracted struggle over the terms of the new social contract-a struggle waged not only in the courts but also in the court of public opinion.

The most famous example of this is the constitutional struggle over the New Deal between 1933 and 1942. In the early 1930s the Supreme Court was dominated by conservative Republican judges who feared that the New Deal was out-of-control socialism inconsistent with our nation's basic charter. They struck down President Franklin D. Roosevelt's National Recovery $\mathrm{Act}^{2}$ and other legislation protecting coal miners ${ }^{3}$ and

${ }^{2}$ Schechter Poultry Co. v. United States, 295 U.S. 495 (1935).

${ }^{3}$ Carter v. Carter Coal Co., 298 U.S. 238 (1936). 


\section{THE COURT AFFIRMS THE SOCIAL CONTRACT}

railroad employees. ${ }^{4}$ Roosevelt responded with a new round of state building, sometimes called the Second New Deal. In 1937 Justice Owen Roberts joined the liberal justices in a pair of five-to-four decisions upholding a state minimum wage $\operatorname{law}^{5}$ and the National Labor Relations Act, ${ }^{6}$ thus ratifying key aspects of the Roosevelt program. Over the next few years, Roosevelt made nine new appointments to the Supreme Court, and this Court legitimated the New Deal regime in a series of landmark opinions.

Contrast this with the civil rights revolution and the Great Society. By 1962, the Warren Court was staffed with liberal Republicans and Democrats who generally supported Kennedy/Johnson liberalism. The justices upheld the Civil Rights Act of $1964^{7}$ and the Voting Rights Act of $1965,{ }^{8}$ and precedents established during the New Deal ensured that Great Society programs would be constitutional. The real constitutional struggle begins in 1968, when Richard Nixon appointed four new conservative justices to the Court in his first term. These new justices accepted and ratified the changes of the 1960s, but also limited them in important ways. They made clear that the welfare state was constitutionally permissible but not constitutionally required, held that education was not a fundamental

${ }^{4}$ R.R. Ret. Bd. v. Alton R.R. Co., 295 U.S. 330 (1935).

${ }^{5}$ West Coast Hotel Co. v. Parrish, 300 U.S. 379 (1937).

${ }^{6}$ Nat'l Labor Rel. Bd. v. Jones \& Laughlin Steel Corp., 301 U.S. 1 (1937).

${ }^{7}$ Heart of Atlanta Motel v. United States, 379 U.S. 241 (1964);

Katzenbach v. McClung, 379 U.S. 294 (1964).

${ }^{8}$ South Carolina v. Katzenbach, 383 U.S. 301 (1966); Katzenbach v. Morgan, 384 U.S. 641 (1966). 


\section{THE COURT AFFIRMS THE SOCIAL CONTRACT}

right, ${ }^{9}$ limited the use of busing to achieve racial integration, ${ }^{10}$ and halted the Warren Court's revolution in criminal procedure. The changes in the social contract were ratified, but on more conservative terms.

Flash forward to today. During his first term in office, President Barack Obama made health care his signature issue. The Patient Protection and Affordable Care Act of 2010 (ACA) made the most significant change to the American social contract since the Great Society programs of the 1960s. It realized the long-held dream of progressives of universal and affordable care for everyone in the United States.

By the time the ACA was passed, however, the nature of the party system had radically changed. The New Deal and the Great Society had support from liberal and moderate Republicans as well as Democrats. But by 2010, there were almost no moderate Republicans left. The ACA was passed solely with Democratic votes, and the two parties were at loggerheads over the nature of the social contract. The new radical Republican Party wanted to roll back important aspects of the social safety net - the Paul Ryan budget was a blueprint for this new dispensation. Conversely, Democrats wanted to complete their long struggle for basic rights of health care.

Not surprisingly, the Affordable Care Act was challenged in the courts almost as soon as it was passed. A change this big in the social contract needed ratification by the federal courts. That is what this litigation was always about, and everybody knew it.

The litigation strategy was complicated. Opponents knew that most of the act was perfectly constitutional under long-standing precedents. They needed to find a weak spot in the law that, once overturned, would throw the entire Affordable Care Act into jeopardy. They hoped their

\footnotetext{
${ }^{9}$ San Antonio Indep. Sch. Dist. v. Rodriguez, 411 U.S. 1 (1973).

${ }^{10}$ Milliken v. Bradley, 418 U.S. 717 (1974).
} 


\section{THE COURT AFFIRMS THE SOCIAL CONTRACT}

challenge would work like Luke Skywalker's well-aimed shot that brought down the entire Death Star.

But the task was even more challenging than this. Most Republican politicians don't actually want to strip the federal government of most of the powers to regulate, tax, and spend that came with the New Deal. That is because Republican politicians want to use those powers to promote Republican policies, like income tax breaks for corporations, new business-friendly environmental regulations, limits on abortion, national tort reform, and partial privatization of Social Security (which, ironically, would require individuals to purchase securities and pension plans from private companies). What opponents wanted, in short, was a constitutional challenge so precise and so narrowly targeted that it would take out one and only one law - the Patient Protection and Affordable Care Act of 2010 - while leaving everything else standing for the next Republican majority.

The opponents seized on the individual mandate to purchase insurance as their most likely target. Ironically, it was a Republican idea, offered in response to President Clinton's failed health care proposal. Nevertheless, the attack on the individual mandate captured an important theme in the radical Republican vision of the social contract: the government should not force some people to buy insurance that would effectively subsidize health care for others. Moreover, because federal laws normally don't use mandates directed at the general public, the challenge would just take out the mandate and leave virtually every other federal law in place.

The opponents also attacked the ACA's Medicaid expansion, which sought to bring subsidized health care to millions of poorer Americans. Once again, the challenge reflected unhappiness with income redistribution in the new regime. Expanding Medicaid to cover everyone up to 133 percent of the poverty line would unfairly divert federal tax dollars to the poor and shift money to states with more poor people.

If either the mandate challenge or the Medicaid challenge succeeded, opponents would then argue that the entire statute had to fall, 


\section{THE COURT AFFIRMS THE SOCIAL CONTRACT}

because the Affordable Care Act had no severability clause. In this way, the opponents could wipe Obamacare off the books with a single stroke, something they could never have done through the ordinary political process.

The stage was now set for the Supreme Court to decide whether to ratify the Democratic changes to the social contract. Would the Court act like the old Court that struck down the National Recovery Act and minimum wage laws? Would it be like the Warren Court that happily ratified the civil rights revolution? Or would it be like the Nixon Court that accepted the 1960s but on more conservative terms?

Four justices of the Supreme Court-Anthony Kennedy, Antonin Scalia, Clarence Thomas, and Samuel Alito-swallowed the radical Republican strategy hook, line, and sinker. Having decided that the individual mandate and the Medicaid expansion were unconstitutional, they sought to leverage that conclusion to strike down the entire law, including features that had nothing to do with the individual mandate or the Medicaid expansion.

Chief Justice Roberts thought this a bridge too far. He joined with the four liberals to uphold the Affordable Care Act, thus placing the Supreme Court's stamp of approval on the most important piece of social welfare legislation since the 1960s. But he exacted a price for this legitimation.

Roberts held that the individual mandate could not be justified by Congress's power to regulate interstate commerce. If it was constitutional, it was only as a tax, which gave people a choice to purchase health insurance or pay a small penalty. As I have argued for many years, this is, in fact, the correct interpretation of what the mandate does. ${ }^{11}$ Once this point is accepted, the argument for the mandate's constitutionality is straightforward, and Roberts quickly showed why this was true.

${ }^{11}$ Jack M. Balkin, Jack M. Balkin, The Constitutionality of the Individual Mandate for Health Insurance, 362 NEw ENG. J. MED. 482-483 (2010). 


\section{THE COURT AFFIRMS THE SOCIAL CONTRACT}

The crucial point, however, is that Roberts's reasoning captures the dual nature of judicial legitimation. He has said to Congress: "You may compel people to enter into commercial transactions like the insurance mandate, but you may not do so as a direct order under the commerce power. Instead, you must do it through the taxing power, always giving people the choice to pay a tax instead. And as long as you structure the mandate as a tax, the people's rights are protected because they always have the right to throw their elected representatives out of office if they don't like the tax." Roberts's opinion thus harks back to a basic source of legitimacy enshrined in the American Revolution: "No taxation without representation." The converse of this proposition, Roberts tells us, is that if you have been represented, and if you can punish your representatives for passing new taxes, your rights have been respected. This logic accepts the new social contract but redefines it in a way more palatable to conservatives.

Roberts then turned to the Medicaid extension. He argued that Congress may create new social programs that expand protection for the poor. But Congress may not tell states that they must accept the new programs or else lose all federal contributions to existing social programs of long standing. The federal government may, if it wants, totally fund the Medicaid extension out of its own pocket without any help from the states. It may abolish the old version of Medicaid and create a new version in its place identical to the expanded version. What it may not do, Roberts argued, is to leverage states' dependence on federal money in established social welfare programs to compel states to participate in new social welfare programs. There are various problems with this solution, and it will probably require years of litigation to clarify the rules going forward. But the important point is that, here again, Roberts is both legitimating and redefining the new social contract in a more conservative way.

Some have called Roberts's opinion statesmanlike, putting aside personal ideology to apply the law. Others have called it clever, handing conservatives an ideological victory while giving Democrats a policy result they like. My own view is that the Court as a whole performed the 


\section{THE COURT AfFIRMS THE SOCIAL CONTRACT}

traditional function of federal judges in our constitutional system. The political branches sought to build out the American state and change the terms of the American social contract. The Court legitimated this result, but set new ground rules for politics going forward.

What does the decision mean in terms of constitutional doctrine? Much will depend on who wins the next several presidential elections. If the Republicans dominate American politics in the decades to come, Roberts's opinion will seem much more conservative than it does now, precisely because Roberts will be assisted by a series of new conservative Supreme Court appointments. They will remake the Constitution in their own image. If the Democrats continue to hold the presidency, the Supreme Court may regain a liberal majority for the first time since the late 1960s, and the Constitution will look appreciably different. But whoever wins, health care reform is here to stay. The social contract in America has forever changed. That is the lasting legacy of President Obama's efforts, and the lasting legacy of the Supreme Court's decision. 